\title{
MECHANICAL CHARACTERIZATION OF POLYMERIC FILMS BASED ON COPOLYMERS OF STYRENE AND BUTYL ACRYLATE OBTAINED BY HETEROGENEOUS POLYMERIZATION IN SEMICONTINUOUS
}

Mercedes Puca-Pacheco*a ${ }^{* a}$ M. Guadalupe Neira-Velázquez ${ }^{\mathrm{b}}$, Gonzalo Canché-Escamilla $^{\mathrm{c}}$

\begin{abstract}
The aim of this work was to synthesize copolymers of styrene (St) and butyl acrylate (AB) cross-linked with allyl methacrylate by semicontinuous heterogeneous polymerization in order to study the mechanical properties of the polymeric films prepared from the latexes obtained. Copolymer latexes were stable and nanoparticles with spherical morphology were observed by Transmission Electron Microscopy (TEM). The latexes had final conversions between 92,5 and $97,0 \%$, which were determined by the gravimetric method, and a solids content close to $20 \%$. The nanoparticles of latex had an average diameter of 59,$1 ; 55,1$ and $49,0 \mathrm{~nm}$ for monomer dosing rates of 0,$75 ; 0,45$ and $0,15 \mathrm{~g} / \mathrm{min}$, respectively.

By means of mechanical characterization of the polymeric films and according to the statistical analysis, it was found that when the monomer dosage rate decreased in the synthesis, the mean particle diameter and molecular weight also decreased, and with it a decrease in its Young's Modulus (MPa).
\end{abstract}

Key words: Polystyrene, polymeric films, mechanical properties, semicontinuous, polymerization.

\footnotetext{
${ }^{a}$ Facultad de Química e Ingeniería Química, Universidad Nacional Mayor de San Marcos UNMSM. Av. Germán Amézaga N³75, Lima 01, CP 15081, Perú. email: mpucap@gmail.com

${ }^{b}$ Centro de Investigación en Química Aplicada, Blvd. Enrique Reyna Hermosillo, No. 140, Col. San José de los Cerritos, CP. 25294, Saltillo, Coahuila, México.

c Centro de Investigación Científica de Yucatán A.C., Calle 143, No. 130, CP 97200, Mérida, Yucatán, México
} 


\title{
CARACTERIZACIÓN MECÁNICA DE PELÍCULAS POLIMÉRICAS BASADAS EN COPOLÍMEROS DE ESTIRENO Y ACRILATO DE BUTILO OBTENIDAS POR POLIMERIZACIÓN HETEROGÉNEA EN SEMICONTINUO
}

\begin{abstract}
RESUMEN
El objetivo de este trabajo fue sintetizar un copolímero de estireno (St) y acrilato de butilo (AB) entrecruzado con metacrilato de alilo mediante polimerización heterogénea semicontinua con el fin de estudiar las propiedades mecánicas de películas poliméricas preparadas a partir de los látex obtenidos. Los látex de copolímero fueron estables y las nanopartículas con morfología esférica se observaron mediante Microscopía Electrónica de Transmisión (TEM). Los látex tuvieron conversiones finales entre 92,5 y 97,0\%, las cuales fueron determinadas por el método gravimétrico, y un contenido de sólidos cercano al 20\%. Las nanopartículas de látex tenían un diámetro medio de 59,1; 55,1 y 49,0 nm para velocidades de dosificación de monómero de 0,$75 ; 0,45$ y $0,15 \mathrm{~g} / \mathrm{min}$, respectivamente. Mediante la caracterización mecánica de las películas poliméricas y según el análisis estadístico, se encontró que cuando disminuía la velocidad de dosificación de monómeros en la síntesis, también disminuían el diámetro medio de partícula y el peso molecular, y con ello una disminución de su Módulo de Young (MPa).
\end{abstract}

Palabras claves: Poliestireno, películas poliméricas, propiedades mecánicas, semicontinuo, polimerización.

\section{INTRODUCTION}

In the last years, interest in obtaining new materials with better mechanical characteristics and properties than those of the materials already known has increased in order to satisfy the modern technology needs. Among the materials of great interest are the polymeric materials, and to obtain them there are many polymerization techniques, for instance: emulsion and microemulsion polymerization, which have many advantages over other polymerization techniques. These advantages include: better control of reaction temperature, high rates of reaction, higher molecular weights ( $>1 \times 106 \mathrm{~g} / \mathrm{mol}$ ), possibility to control the molecular weight (using chain transfer agents), low viscosity latex and elimination of environmental pollution risks ${ }^{1,2}$.

However, one of the drawbacks of microemulsion polymerization are the high concentrations of surfactant used and the low polymer/surfactant ratio in the final latex. To mitigate this problem, Rabelero et al. (1997) reported the microemulsion of styrene polymerization, where polystyrene latex with high content of solids (around 40\%) was obtained by adding a 
monomer semi-continuously during the polymerization process. These authors reported an increase in the polymer/surfactant ratio of up to $3 / 1$. Besides, this ratio was improved up to $10 / 1^{3,4}$.

Currently, the semicontinuous emulsion copolymerization process is widely used in the industry due to a great number of advantages compared to the conventional batch process. These advantages include: The control of polymerization rate, particle diameter, particle morphology and chemical composition of copolymer ${ }^{5,6}$.

Synthetized polymers are aqueous emulsions of acrylic polymers that are environmentally friendly and can be used in coatings and adhesives ${ }^{7}$. The presence of an elastomer such as butyl acrylate in the copolymer allows the film formation allowing chain interdifusion inside the polymer, and this phenomenon will now occur if just polystyrene is used.

The physical and mechanical properties of thin polymer films are important from both an academic and an industrial point of view. These properties are affected not only by the nature of the polymer ${ }^{2}$, but also by the method of film preparation and conditioning.

By means of the present study, poly (styrene-co-butyl acrylate) were synthesized by semicontinuous heterogeneous polymerization, and it was found that as the monomer feed rate decreases, copolymer nanoparticles with smaller diameter and lower molecular weight are obtained causing a decrease in their Young's modulu.

\section{EXPERIMENTAL PART}

\section{Materials}

Styrene (St) with $99,0 \%$ of purity was obtained from Merck (USA), and was passed through a TR-7 column to eliminate the inhibitor ( $t$-Butylcatechol). The butyl acrylate (AB) with a purity of $99,0 \%$ obtained also from Merck, was passed through a HR-4 column to eliminate the inhibitor (hydroquinone methylester). Allyl methacrylate (ALMA) with 99,0\% of purity was obtained from Sigma-Aldrich (USA). Sodium dodecyl sulfate (SDS) was obtained from Merck Peruana S.A. with $99,0 \%$ of purity. Ammonium persulfate (APS) obtained from Merck with $99,5 \%$ of purity was used as initiator. Hydroquinone (HQ) with 99,5\% of purity was purchased from Merck and was used as a reaction inhibitor. Bidistilled water with a conductivity lower than $6 \mu \mathrm{S} / \mathrm{cm}$ was used.

\section{Synthesis of poly(styrene -co-butyl acrylate) by semicontinuous heterogeneous polymerization.}

Polymerization reactions were performed at $70{ }^{\circ} \mathrm{C}$ in a $300 \mathrm{ml}$ reactor with three dill bits. First $0,5 \mathrm{~g}$ of SDS was dissolved in $79,3 \mathrm{~g}$ of bisdestilled water. To that end, they were in constant shaking at $450 \mathrm{rpm}$, and to keep an inert atmosphere during the reaction, nitrogen gas was bubbled for 1 hour and then $0,2 \mathrm{~g}$ of APS initiator was poured, and after that, dosing of the organic mixture composed of $8 \mathrm{~g}$ of styrene, $12 \mathrm{~g}$ of butyl acrylate and 0,2 $\mathrm{g}$ of allyl 
methacrylate (crosslinking agent) was initiated. For dosing of reactives, a New Era NE 300 syringe pump was used (See Figure 1). Polymerization reactions were carried out with mass flow dosing of 0,$15 ; 0,45$ and $0,75 \mathrm{~g} / \mathrm{min}$. Once the dosing finished, an additional hour was given to complete the polymerization reaction.

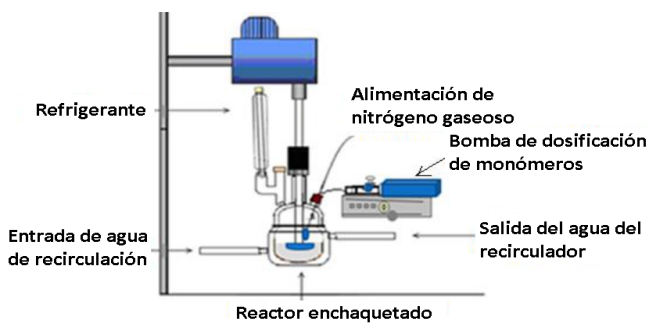

Figure 1. Diagram of the reaction system of the semi-continuous heterogeneous polymerization.

Source: self made.

Samples were taken during the polymerization at different reaction times to determine conversion. Sampling was also carried out at the end of the polymerization to determine the particle diameter.

\section{Experimental Design}

For this study, an experimental design was proposed through a factor analysis $2^{2}$ with center point and the two factors of study were the diameter of the poly(styrene co-butyl acrylate) particle and the temperature of film formation and of two levels for each factor: high level $(+)$ and low level (-). Additionally, in this method center points was added to the design $2^{2}$ (see Table 1). The response variables for the study were the mechanical properties of films such as Young's modulus, yield strength, deformation at break and hardness.

Table 1. Experimental Design.

\begin{tabular}{ccc}
\hline $\begin{array}{c}\text { Notation } \\
(\mathrm{Dn})(\mathrm{DT})\end{array}$ & $\begin{array}{c}\text { Particle diameter } \\
(\mathrm{Dn})\end{array}$ & $\begin{array}{c}\text { Drying temperature } \\
(\mathrm{DT})\end{array}$ \\
\hline$(-)(-)$ & 49,0 & $\left({ }^{\circ} \mathrm{C}\right)$ \\
$(-)(+)$ & 49,0 & 25 \\
$(+)(-)$ & 59,1 & 75 \\
$(+)(+)$ & 59,1 & 25 \\
$(0)(0)$ & 55,1 & 75 \\
\hline
\end{tabular}

\section{Polymeric Film Formation}

Polymeric films were formed using poly(styrene-co-butyl acrylate) latexes obtained through a semicontinuous heterogeneous polymerization. The latexes obtained in this step, were deposited in petri dishes and dried during 7 days at temperatures of 25,50 and $75^{\circ} \mathrm{C}$. 


\section{Characterization}

Polymerization kinetics were studied through the gravimetric method.

Particle size measurements were made by light scattering (DLS) on a Malvern Zetasizer Nano-ZS90 at $25^{\circ} \mathrm{C}$.

The thermogravimetric analysis (TGA) to evaluate the thermal stability and the decomposition temperature of the copolymer, was carried out in an equipment TA Instruments model Q500. The samples were analyzed from $0-800^{\circ} \mathrm{C}$ at a heating rate of $10^{\circ} \mathrm{C} / \mathrm{min}$ under an inert atmosphere of nitrogen gas.

To determine the glass transition temperature, the Differential Scanning Calorimeter TA Instruments model Q200 was used. For the analysis, $10 \mathrm{mg}$ of sample was weighed into aluminum trays, sealed and placed in the equipment. The analysis conditions were established from -75 to $150{ }^{\circ} \mathrm{C}$ with a heating rate of $10^{\circ} \mathrm{C} / \mathrm{min}$ under a nitrogen gas flow of $50 \mathrm{~mL} /$ min to maintain an inert atmosphere and three scans were carried out for each sample, a first heating was to erase the thermal history of the material, cooling and a second heating to determine the thermal transitions of the material.

The average molecular weights in number, $\mathrm{Mn}$, and polydispersity index (Mw/Mn), of the styrene and butyl acrylate copolymers obtained in the present work, were determined in a Hewlett Packard (HPLC 1100) equipment, using polystyrene standards and tetrahydrofuran (THF) as mobile phase, at room temperature.

For the morphological study, a JEOL CX-100 Transmission Electron Microscope (TEM) was used. To carry out this test, two latex drops were used and were diluted in $5 \mathrm{ml}$ of bistilled water and deposited on a Formvar-coated grid, and then they were dried and observed in TEM under an acceleration voltage of $30 \mathrm{kV}$.

Stress and hardness tests were among the mechanical tests performed. For the stress test of poly(styrene-co-butyl acrylate) films, they were cut with the following dimensions: $10 \mathrm{~mm}$ wide, $50 \mathrm{~mm}$ long and with a thicknes of 20 micron approximately. The device used to carry out the mechanical tests was a United SFM-10 universal testing machine and using a 20 pound-strength cell. To determine the deformation rate, the ASTM, D-882 method was used. To determine hardness, the ASTM D2240 method was used, using a PTC Instrument Model 320 Shore A Durometer.

\section{Statistic Analysis}

Shapiro test was used to evaluate if the data were according to a normal distribution, and the variance analysis of response variables (mechanical properties of films) was performed. The statistical software STATGRAPHICS Centurion XVI was used and the analysis of the effects was carried out with a significance level of $5 \%$. 


\section{RESULTS AND DISCUSSIONS}

\section{Copolymer Synthesis}

Figure 2 shows the instantaneous conversion curve $(\mathrm{Xi})$ against normalized time $\left(\mathrm{t}_{\mathrm{rel}}\right)$ defined as the relationship of sampling time with respect to total addition time, for the semicontinuous polymerization process of styrene and butyl acrylate. Here the instantaneous conversion is the monomer fraction added to time tr that is converted to a polymer, since the global conversion is the total monomer fraction added in the process that has reacted on time tr.

Figure 2 also shows that the instantaneous conversion increases quickly and reaches high values at relatively short times $(\operatorname{tr}<0,3)$. For $\operatorname{tr}>0,3$; the instantaneous conversion increases very slowly and remains high through all the reaction. In addition, since styrene and butyl acrylate have a low solubility in water, polymerization is carried out through micellar nucleation, instead of homogeneous nucleation.

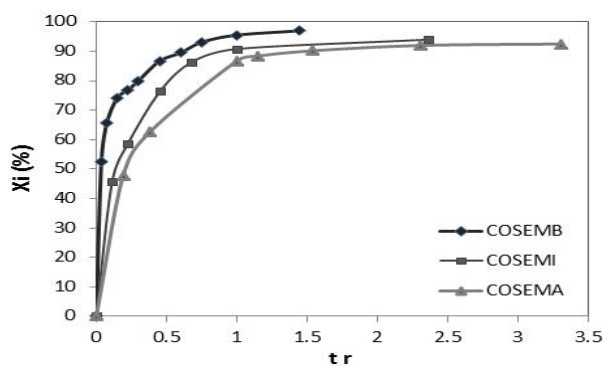

Figure 2. Instantaneous conversion curves (Xi \%) vs. relative time (tr) in copolymerization of styrene and butyl acrylate at a high (COSEMA), intermediate (COSEMI) and low (COSEMB) monomer dosing rate, respectively.

Moreover, final conversions (Xi \%) of 92,5; 94,0 and 97,0\% were obtained at a high (COSEMA), intermediate (COSEMI) and low (COSEMB) monomer dosing rate, respectively. The average diameters of the nanoparticles of final latexes were 59,$1 ; 55,1$ and $49 \mathrm{~nm}$ for high (COSEMA), intermediate (COSEMI) and low (COSEMB) dosing rates, respectively. The instantaneous monomer conversion was higher than $92,5 \mathrm{wt} \%$ indicating that the monomers were reacted as they were fed into the reactor. Despite the difference in monomer reactivity ratios, the semicontinuous reactions carried out under starved monomer conditions led to the formation of a constant composition polymer with the same composition as the monomer feed.

In batch emulsion polymerization, the composition of the copolymer is controlled by the reactivity of styrene with respect to butyl acrylate. According to the values of the reactivity ratio of the monomers reported for this $\operatorname{system}^{8}(\mathrm{rSt}=1,006$ and $\mathrm{rBA}=0,232)$, a random copolymer is obtained with a large proportion of St in the copolymer. However, in the semicontinuous process, at low monomer addition rates, a random copolymer is obtained with a composition similar to the feed ratio ${ }^{9}$. 
Therefore, the particle size of copolymers decreases when the dosing rate of the monomer mixture composed of styrene and butyl acrylate decreases in the semicontinuous heterogeneous polymerization (see Table 2). Also, the instantaneous conversions decreased through the reaction when the dosing rate of the monomer was increased (see Table 2 y Figure 2).

Table 2. Particle diameter and final Corversion.

\begin{tabular}{|c|c|c|c|c|c|}
\hline $\begin{array}{l}\text { Notation } \\
\text { (Dn)(DT) }\end{array}$ & $\begin{array}{l}\text { Particle } \\
\text { diameter } \\
(\mathrm{Dn}) \\
(\mathrm{nm})\end{array}$ & \begin{tabular}{l}
\multicolumn{1}{c}{ Drying } \\
temperature \\
$(\mathrm{DT})$ \\
$\left({ }^{\circ} \mathrm{C}\right)$
\end{tabular} & $\begin{array}{c}\text { Monomer ratio } \\
r=\frac{m S t(g)}{m A B(g)}\end{array}$ & $\begin{array}{l}\text { Dosing flow } \\
(\mathrm{g} / \mathrm{min})\end{array}$ & $\begin{array}{c}\text { Conversion } \\
\text { final } \\
(\% \mathrm{Xi})\end{array}$ \\
\hline$(-)(-)$ & 49,0 & 25 & $8 / 12$ & 0.15 & 97.0 \\
\hline$(-)(+)$ & 49,0 & 75 & $8 / 12$ & 0.15 & 97.0 \\
\hline$(+)(-)$ & 59,1 & 25 & $8 / 12$ & 0.75 & 92.5 \\
\hline$(+)(+)$ & 59,1 & 75 & $8 / 12$ & 0.75 & 92.5 \\
\hline$(0)(0)$ & 55,1 & 50 & $8 / 12$ & 0.45 & 94.0 \\
\hline
\end{tabular}

This similar development was reported by Lopez et al., (2006) where a semicontinuous heterogeneous polymerization process was carried out for the synthesis of poly (MethylMethacrylate) varying the monomer dosing rate $^{10}$. This effect explains that the lower the monomer dosing rate, avid conditions of monomer are achieved, allowing the formation of a greater number of particles and lower growth speed of the particles formed ${ }^{11}$, and thereby, smaller particles are obtained due to the nucleation of a great number of smaller polymer particles.

\section{Molecular weight and thermal analysis.}

Table 3 shows the molecular weight values for the different polymerization reactions, at different dosage flows and drying temperatures of the films. In general, the molecular weights obtained at a high dosage speed of $0,75 \mathrm{~g} / \mathrm{min}$ are greater than those reached by those dosage speed of $0,45 \mathrm{~g} / \mathrm{min}$ and $0,15 \mathrm{~g} / \mathrm{min}$. Number average molecular weights $(\mathrm{Mn})$ were obtained between values of $205526 \mathrm{~g} / \mathrm{mol}$ and $287055 \mathrm{~g} / \mathrm{mol}$, being values lower than those normally obtained by microemulsion polymerization, in which high molecular weights can be reached $\left(\mathrm{Mn}>10^{6} \mathrm{~g} / \mathrm{mol}\right)$. In the semicontinuous polymerization process, it was obtained that by decreasing the monomer dosage flow, polymers with smaller particle size, lower molecular weight and lower glass transition temperature are obtained. Particles with polydispersities $(\mathrm{Mw} / \mathrm{Mn})$ within the range of 1,215-1,347 were obtained. 
Table 3. Average particle diameters (Dn), number average molecular weight (Mn) Polydispersity index (Mw/Mn), glass transition temperature (Tg) and TGA.

\begin{tabular}{|c|c|c|c|c|c|c|c|}
\hline $\begin{array}{l}\text { Notation } \\
(\mathrm{Dn})(\mathrm{DT})\end{array}$ & $\begin{array}{l}\text { Particle } \\
\text { diameter } \\
(\mathrm{Dn}) \\
(\mathrm{nm})\end{array}$ & $\begin{array}{l}\text { Drying } \\
\text { temperatura } \\
(\mathrm{DT}) \\
\left({ }^{\circ} \mathrm{C}\right)\end{array}$ & $\begin{array}{l}\text { Number } \\
\text { average } \\
\text { molecular } \\
\text { weight } \\
(\mathrm{Mn})\end{array}$ & $\begin{array}{l}\text { Weight } \\
\text { average } \\
\text { molecular } \\
\text { weight } \\
(\mathrm{Mw})\end{array}$ & $\begin{array}{l}\text { Polydispersity } \\
\mathrm{PDI}=\mathrm{Mw} / \mathrm{Mn}\end{array}$ & $\begin{array}{l}\text { Glass } \\
\text { transition } \\
\text { temperature } \\
(\mathrm{Tg}) \\
\left({ }^{\circ} \mathrm{C}\right)\end{array}$ & $\begin{array}{l}\text { TGA } \\
\left({ }^{\circ} \mathrm{C}\right)\end{array}$ \\
\hline$(-)(-)$ & 49,0 & 25 & 205526 & 249714 & 1,215 & 2,70 & 403,64 \\
\hline$(-)(+)$ & 49,0 & 75 & 209129 & 260366 & 1,245 & 3,20 & 406,75 \\
\hline$(+)(-)$ & 59,1 & 25 & 287055 & 379200 & 1,321 & 6.52 & 403,27 \\
\hline$(+)(+)$ & 59,1 & 75 & 284317 & 370181 & 1,302 & 6.04 & 408,99 \\
\hline$(0)(0)$ & 55,1 & 50 & 251082 & 338208 & 1,347 & 3,62 & 408,82 \\
\hline
\end{tabular}

The glass transition temperatures were between 2,70 and $6,52^{\circ} \mathrm{C}$ and it is important to know them since they determine the Minimum Film Formation Temperature (MFFT) of latex, since at temperatures higher than the Tg the formation of films, and below said temperature, the films fully solidify increasing their rigidity, and therefore, they would not form continuous films (see Table 3)

The TGA values were between 403,64 and $408,99{ }^{\circ} \mathrm{C}$, which indicates that at these temperaturas, thermal decomposition occurs with the formation of volatile reaction products. The behavior in the molecular weight reported here has also been observed by other authors (Xue et al., 2005; Al-Bagoury and Yaacoub, 2003) ${ }^{12,13}$. When the monomer dosage flow increases, the monomer concentration in the particles is also increased, since the polymerization rate is directly proportional to the monomer concentration in the particles, the polymerization rate is also increased. This implies that the spreading chains add more monomeric units to their structure before undergoing any termination reaction, which increases the molecular weight.

\section{Morfology study}

Figures 3 (a), (b) and (c) show the micrographs obtained by TEM. They show the spheroidal form and the homogeneous sizes of the nanoparticles of poly(styrene -co- butyl acrylate).
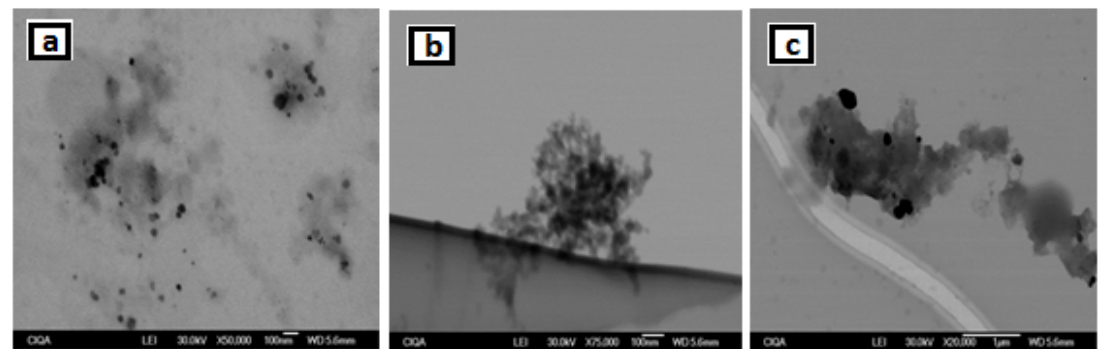

Figure 3. Micrographs of nanoparticles of copolymers obtained through Transmission Electron Microscope (TEM) when a) low monomer dosing rate; b) intermediate dosing rate and c) high monomer dosing rate were used in the copolymer synthesis. 


\section{Film properties}

Table 4 shows the Young's modulus, the yield strength, the percentage of deformation and hardness of the polymeric films. It can be said that there is a slight dependence of the mechanical properties on the formation temperature of the polymeric films and this is related to the high energy of activation and consequently, to the high interdiffusion of copolymer chains $^{14}$.

For the formation of the polymeric film from latex, three stages take place in the drying process: a) Evaporation where the ordering and concentration of the particles occurs and the evaporation rate is constant (Steward et al., 2000) ${ }^{15}$; b) The deformation and coalescence of the particle where cohesion between the particles occurs, promoted by the force of the surface and allows their compaction; c) Increase of the cohesive force by the additional gradual coalescence of particles and interdiffusion of the. ends and segments of the copolymer chain and the formation of chain entanglements ${ }^{16}$; and they are maintained by electrostatic and/or steric forces as a result of the presence of functional groups in the polymer chains. Therefore, among the possible links would be between the crosslinking agent (ALMA) and the main chain made up of Polystyrene and butyl polyacrylate.

Table 4. Elastic modulus, yield strength, deformation at break and hardness of polymeric films obtained from poly(styrene- co-butyl acrylate) latex through semicontinuous heterogeneous polymerization with high (COSEMA), low (COSEMB) and intermediate (COSEMI) dosing rate at temperatures of $25 ; 50$ and $75^{\circ} \mathrm{C}$.

\begin{tabular}{lccccccc}
\hline Sample & $\begin{array}{c}\text { Notación } \\
(\mathrm{Dn})(\mathrm{DT})\end{array}$ & $\begin{array}{c}\text { Particle } \\
\text { diameter } \\
(\mathrm{Dn})\end{array}$ & $\begin{array}{c}\text { Drying temperature } \\
\text { of film (DT) } \\
\left({ }^{\circ} \mathrm{C}\right)\end{array}$ & $\begin{array}{c}\text { Young's } \\
\text { modulus (E) } \\
(\mathrm{MPa})\end{array}$ & $\begin{array}{c}\text { Strength } \\
(\mathrm{MPa})\end{array}$ & $\begin{array}{c}\text { Deformation at } \\
\text { break } \\
(\%)\end{array}$ & $\begin{array}{c}\text { Hardness } \\
\text { Short A }\end{array}$ \\
\hline COSEMB & $(-)(-)$ & 49,0 & 25 & $1,22 \pm 0,13$ & $2,31 \pm 0,42$ & $1017 \pm 80$ & $16,6 \pm 0,52$ \\
COSEMB & $(-)(+)$ & 49,0 & 75 & $1,31 \pm 0,13$ & $2,97 \pm 0,57$ & $1009 \pm 36$ & $19,2 \pm 0,42$ \\
COSEMA & $(+)(-)$ & 59,1 & 25 & $1,77 \pm 0,49$ & $2,37 \pm 0,52$ & $1078 \pm 141$ & $16,8 \pm 0,79$ \\
COSEMA & $(+)(+)$ & 59,1 & 75 & $2,06 \pm 0,26$ & $2,92 \pm 0,55$ & $831 \pm 87$ & $18,4 \pm 0,84$ \\
COSEMI & $(0)(0)$ & 55,1 & 50 & $1,28 \pm 0,18$ & $1,58 \pm 0,24$ & $889 \pm 72$ & $17,6 \pm 0,52$ \\
\hline
\end{tabular}

Furthermore, the use of the crosslinking agent, such as the allyl methacrylate improves the copolymer solvent resistance, as well as its mechanical properties (higher rigidity). In this work, $1 \% \mathrm{w}$ of the total mass of monomers was used. The use of allyl methacrylate (crosslinking agent) also improves the copolymer optical properties for a possible application of this material in the microelectronic field ${ }^{17}$.

Therefore, by means of semicontinuous polymerization, copolymer particles are obtained with smaller particle sizes, high solids content and lower molecular weights than those reported by microemulsion polymerization. Through the present study it is shown that the mechanical properties depend on the diameter of the particle, its molecular weights and also the production process, in this case the heterogeneous semi-continuous polymerization was 
used. Also, as the monomer dosage flow decreases, the particle size and molecular weight decrease, causing the polymers to have lower Young's module.

Table 5 shows the variance analysis for Young's modulus, yield strength, deformation at break (\%) and hardness. According to Table 4, when the temperature increases, hardness increases. This is due to the fact that the material rigidity increases due to cross-links resulted from the increase of the film formation temperature.

Based on these results of the Young's modulus shown in Table 5, the Shapiro-Wilk test (normality test) was performed. This test indicates that the data were according to a normal distribution with $(\mathrm{p}$-value $=0,01)=0,7300$.

When all the results showed a normal distribution, a variance analysis of the results obtained from the Young's modulus (MPa) was performed, which are shown in Table 5 and it shows that there is no effect of the film formation temperature (p-value $=0,2864$ ), and of the interaction of both factors (film formation temperature and particle size) ( $p$-value $=0,9788$ ). However, the particle diameter conversely affects the Young's Modulus, since the p-value was 0,0131 (a value $<\alpha=0,05$ ). On the other hand, it was found that the polymeric film formation temperature directly affects the hardness of the copolymer since the p-value was 0,0112 .

Table 5. Variance analysis for Young's modulus, yield strength, deformation at break and hardness.

\begin{tabular}{ll}
\hline Effects and interactions & Value-P* $^{*}$ \\
\hline Young's Modulus $(\boldsymbol{E}):$ & \\
Main effects & \\
A:Particle diameter & 0,0131 \\
B:Temperature & 0,6754 \\
AB & 0,9788 \\
Yield Strength: & \\
Main effects & \\
A: Particule diameter & 0,1835 \\
B: Temperature & 0,4820 \\
AB & 0,8052 \\
Deformation at Break: & \\
Main effects & \\
A: Particle diameter & \\
B: Temperature & 0,2093 \\
AB & 0,5268 \\
Hardness: & 0,7352 \\
Main effects & \\
A: Particle diameter & \\
B: Temperature & 0,1307 \\
AB & 0,0112 \\
*Statistic test & 0,8566 \\
\hline
\end{tabular}




\section{CONCLUSIONS}

The synthesis of poly(styrene-co- butyl acrylate) through the semicontinuous heterogeneous polymerization provided spheroidal nanoparticles with particle diameter smaller than $60 \mathrm{~nm}$, with conversions between 93 and $97 \%$, and therefore, high content of solids close to $20 \%$. The particle size of copolymers decreased when the dosing rate of the monomer mixture composed of styrene and butyl acrylate decreased in the semicontinuous heterogeneous polymerization process.

As the styrene and butyl acrylate copolymers with smaller particle diameter $(\mathrm{Dn}<59 \mathrm{~nm})$ and low molecular weight were obtained, they presented a lower Young's modulus $(\mathrm{E}<2,06$ $\mathrm{MPa})$. However, they presented a greater hardness and in statistics, it has been demonstrated that the particle size and molecular weight have been shown to influence Young's modulus with a confidence level of $95 \%$.

An increase of temperature of polymeric film formation to a lower temperature of the polystyrene glass transition temperature $\left(\mathrm{Tg}=100{ }^{\circ} \mathrm{C}\right.$ ) (rigid polymer) and a higher temperature of the glass transition temperature of poly (butyl acrylate) $\left(\mathrm{Tg}=-50^{\circ} \mathrm{C}\right.$ ) (rubberized polymer), contributes to an increase of the polymer hardness due to cross-links resulting from the presence of double bonds.

\section{ACKNOWLEDGMENTS}

The authors gratefully acknowledge at the Research Center for Applied Chemistry (CIQA, Mexico) for the measurements at the TEM and the Scientific Research Center of Yucatán for the mechanical properties measurements.

\section{REFERENCES}

1. Gilbert RG. Emulsion polymerization. New York: Academic Press; 1995.

2. Puig JE. Microemulsion polymerization. In: Salomone JC, ed. Encyclopedia of polymeric materials. Boca Raton, Florida: CRC Press; 1996. 6: 4333-4341.

3. Rabelero M, Zacarías M, Mendizábal E, Puig JE, Dominguez JM, Katime I. Highcontent polystyrene latex by microemulsion polymerization. Polymer Bulletin. 1997; 38 (6): 695-700.

4. Puca M. Síntesis y caracterización de nanoestructurados mediante polimerización en microemulsión y su aplicación en la formación de películas. [Tesis para optar el título de Doctor en Ciencias en Ingeniería Química]. Guadalajara: Universidad de Guadalajara, Jalisco, México; 2005.

5. Aerdts AM, Theelen SJC, Smit TMC, German AL. Grafting of styrene and methyl methacrylate concurrently onto polybutadiene in semicontinuous emulsion processes 
and determination of copolymer microstructure. Polymer. 1994; 35 (8) 1648-1653.

6. Nunes JD, Asua JM. Theory-Guided Strategy for Nanolatex Synthesis. Langmuir. 2012; 28(19): 7333-7342.

7. Koukiotis CG, Karabela MM, Sideridou ID. Mechanical Properties of Films of Latexes Based on Copolymers BA/MMA/DAAM and BA/MMA/VEOVA-10/DAAM and the Corresponding Self-Crosslinked Copolymers Using the Adipic Acid Dihydrazide as Crosslinking Agent. Prog Organic Coat. 2012; 75: 106-115.

8. Ziaee F, Nekoomanesh M. Monomer reactivity ratios of styrene-butyl acrylate copolymers at low and high conversions. Polymer 1998; 39: 203-207.

9. Sňupárek J, Krška F. Semicontinuous emulsion copolymerization of styrene and butyl acrylate. J Appl Polym Sci. 1976; 20: 1753-1764.

10. López RG, Ledezma R, Treviño ME, Elizalde LE, Pérez-Carrillo LA, Mendizábal E, Puig JE. Semicontinuous heterophase polymerization under monomer starved conditions to prepare nanoparticles with narrow size distribution. J Polym Sci Part A: Polym Chem. 2006; 45, 1463-1473.

11. Sajjadi S. Particle formation under monomer-starved conditions in the semibatch emulsion polymerization of styrene. I. Experimental. J Polym Sci Part A: Polym Chem. 2001; 39, 3940-3952.

12. Xue Y, Jiang W, Zhao Y, Yang W, Fu S, Vormerg LJ. The Effects of Post-Addition Rate on Polymerization Rate and Molecular Weight in Modified Microemulsion Polymerization of MMA. J Macromol Sci Part A: Pure and Appl Chem. 2005; 42:1147-1158.

13. Al-Bagoury $\mathrm{M}$, YaJacoub E. Semicontinuous emulsion copolymerization of 3-O-methacryloyl-1,2:5,6-di-O-isopropylidene- $\alpha$-D-glucofuranose (3-MDG) and butyl acrylate (BA). Monomer feed addition. J Appl Polym Sci. 2003; 90 (8):2091-2102.

14. Cheng KC. Effect of feed rate of monofunctional monomers on structure of hyperbranched copolymers formed by self-condensing vinyl copolymerization in semibatch reactor. Eur Polym J. 2014; 60: 98-105.

15. Steward PA, Hearn J, Wilkinson MC. An overview of polymer latex film formation and properties. Adv Colloid Interface Sci. 2000; 86: 195-267.

16. Koh AYC, Mange S, Bothe M, Leyrer RJ, Gilbert RG. The influence of copolymerization with methacrylic acid on poly(butyl acrylate) film properties. Polymer. 2006; 47: 11591165.

17. Qu J, Cheng J, Wang Z, Han X, Zhao M. Synthesis, thermal and optical properties of crosslinked poly (isobornyl methacrylate-co-butyl acrylate) copolymer films. Optical. Materials. 2014; 36: 804-808 